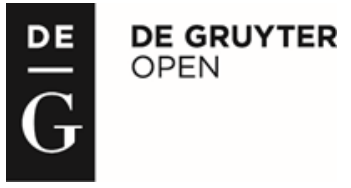

${ }^{*}$ Randall K. Van Schepen

Associate Professor of Art and Architectural History

School of Architecture, Art and Historic Preservation

Roger Williams University

One Old Ferry Road, Bristol, RI 02809 USA

Email: rvanschepen@rwu.edu

\title{
GERHARD RICHTER'S CRITICAL ARTISTIC STRATEGIES: POLITICS, TERRORISM AND WAR
}

\begin{abstract}
The present paper analyzes two artistic strategies employed by Gerhard Richter to deal with painful recent cultural memory. Two works in particular reveal the relative success of Richter's varied artistic strategies addressing contemporary political events: 18. Oktober 1977 (1988) and War Cut (2004). In his series of paintings on the Baader-Meinhof terrorist group, Richter effectively employs his "photopainting" style to address the profoundly disturbing deaths of the Baader-Meinhof group in the 1970s. Richter chose mundane photographic sources for his imagery, denying a hierarchy of "correct" memories of the events and turning photographic indexicality against itself by employing a painterly medium, tinged with nostalgia, to represent it. Richter's photopaintings of Baader-Meinhof thus use the "factual" nature of the photograph while also utilizing an elegiac painterly mist through which an indistinct emotional memory of the past seems to emerge. Richter's blurring of images can thus be understood as a fulcrum on which the undecidability of history itself must be represented. Richter constructs War Cut (2004), on the other hand, as a work and aesthetic experience decidedly at odds with the iconicity of his Baader-Meinhof images by employing arbitrariness and conceptual abstraction.
\end{abstract}

Keywords: Gerhard Richter, cultural memory, terrorism, painting, abstraction, representation

This is not the reason I make paintings, but yes, they can hold time a bit. That's why they are so attractive for us.

Gerhard Richter, (Richter in Storr, 2002: n.p.)

1. Introduction: Richter, History and the Photograph

The oeuvre of the contemporary artist Gerhard Richter is rich in works that problematize our

\footnotetext{
* Randall K. Van Schepen is Associate Professor of Art and Architectural History in the School of Architecture, Art and Historic Preservation at Roger Williams University in Bristol Rhode Island, USA. He has taught Art History at Rice University, The University of Minnesota, The University of Wisconsin-Stout, and St. Olaf College. Focusing on modern and contemporary art and architecture as well as critical theory, his research ranges chronologically over the $20^{\text {th }}$ and $21^{\text {st }}$ centuries with occasional forays into the philosophical foundations of modernist thought in the $18^{\text {th }}$ and $19^{\text {th }}$ centuries. He has published essays on a wide variety of individual artists such as Marcel Duchamp, Ilya Kabakov, Eric Fischl, Sherrie Levine, Jeffrey Silverthorne and Gerhard Richter as well as on theorists and art critics such as Walter Benjamin, Roland Barthes, Leo Steinberg, Alfred Barr, Clement Greenberg and Michael Fried. Conceptual themes that pervade his work include studies of the role of memory in art, the philosophical and spiritual background of modernist criticism, contemporary artist's approaches to memorializing or addressing tragedy/terror, as well as the ambiguous status of the photograph in contemporary and modern theories of art. He lives in Cranston, Rhode Island and Windham, Maine.
} 
contemporary understanding of memory, employing the mnemonic devices of the monument (Two Sculptures for a Room by Palermo, 1971), of the individual photographic snapshot (Uncle Rudi, 1965), of the photo album (Atlas, 1961-), and of the daily newspaper (Eight Student Nurses, 1966). Richter is known as one of the preeminent stylistically diverse contemporary artists, a virtual posterchild for postmodernism, one who masterfully employs both representation and abstraction with a coolly calculated arbitrariness. But of his varied methodologies of artistic production, Richter's photographically-based representational works trouble audiences and critics the most, with critiques ranging from celebrations of their profundity to pronouncements of their trite sentimentality. Some explanation of these polar responses comes from the nature of representational artistic production itself, which often elicits such widely varied responses. However, the main dangers of abstract modes of expression, on the other hand, are that they are read as either derivative of other abstraction or as merely decorative, a style without substance. But representational works are fraught with a wider range of critical perils resulting from a wide range of possible subject matter, the use of varied representational tropes and the context in which the subject is viewed.

In Richter's work, such problematics of representation are further complicated by his wellchronicled dependence on photographic sources for his images. His deployment of photographic reference within painted images mirrors the manner in which photography both fosters and obliterates the formation of modern memories. Richter's attitude regarding the power of the photograph can be contrasted to that of Siegfried Kracauer. If Kracauer's theory proposes that the advent and use of photography irreversibly degrades our modern memory images, Richter's more sanguine attitude about the mnemonic function of photography suggests its possible redemption as an aid for memory. But Richter's is not an unbridled celebration of photography's ability to aid in reflection on the past. Rather, his use of photography within painting acknowledges its limited ability to give an adequate account of the past, something that is achingly clear in his most poignant imagery. Over the last forty years, Richter has consistently used photographic imagery to address contemporary events and recent history, surveying through these iterations the potential uses of the photograph in art. Richter's series of paintings, 18. Oktober 1977 (1988), is perhaps the pinnacle of his career-long meditation on the limits of personal memory and on the manner in which image technologies designed to foster our memories my in fact occlude, replace or supplement the construction of personal and cultural memory.

In what follows I will address Richter's eliciting of memories of recent tragic history in two works that employ quite distinct artistic forms of production: 18. Oktober 1977 (1988) and War Cut (2004). These works reveal Richter's consistent preoccupation with history, a preoccupation that has perhaps reached its representational limit in War Cut. The two works move from the palpable pathos of 18. October 1977, which allows viewers to identify with the prisoners depicted, to the recent War $\mathrm{Cut}$, which seems designed to frustrate any empathic impulse in the viewer. Richter's use of the Baader-Meinhof terrorist events for 18. Oktober 1977 and his addressing the subject of the Iraq war for War Cut indicate his unflinching willingness to bring the most painful recent memories to the forefront of contemporary consciousness. And yet, the question remains as to whether his recent, more conceptual, approach to representing history is one that is adequate to contemporary needs.

\section{18. Oktober 1977: Embodiments of Memory}

Born in East Germany as a member of the first generation of German artists to deal with the legacy of the Second World War, Richter compounds the difficulty of finding or constructing reliable memories by never creating work directly from his experiential memory, but always working from pre-formulated imagery that was already in familial or cultural circulation. In Contemporary Art and Memory, Joan Gibbons applies Marianne Hirsch's term postmemory to this second-hand artistic approach towards cultural memory, especially in reference to Richter's contemporary, Anselm Kiefer (Gibbons citing Hirsch, 2007: 243). ${ }^{1}$ As postwar Germans, Kiefer and Richter often address their

\footnotetext{
${ }^{1}$ Hirsch herself suggests that postmemories are particularly evocative because they are actively constructed by the subject: "Postmemory's connection to the past is thus not actually mediated by recall but by imaginative investment, projection, and creation. To grow up with such overwhelming inherited memories, to be dominated by narratives that preceded one's birth, or one's consciousness, is to risk having one's own stories and experiences displaced, even evacuated, by those of a previous generation" (Hirsch, 2008: 103).
} 
recent traumatic past through an absence of direct reference. As one of the first works created in the West by Richter and his only performance, Gerhard Richter/Konrad Lueg, Leben Mit Pop: Eine Demonstration fur den Kapitalistischen Realismus (1963) is an early indication of a typically oblique angle from which he prompts memories of recent German history. Germans' reflexive suppression of history, Richter's early life in East Germany, and his emotionally conservative nature predispose him to make such obscured connections. Richter's direct experience with what he saw as the blinding effects of the dominant political and economic systems of the middle third of the twentieth century (fascism, communism, and capitalism) create a pronounced circumspect and uncommitted attitude about any ideological system. His work never directly engages in ideological or political skirmishes. Subject to critiques accusing him of aestheticizing history or violence, Richter believes that a comprehensive political or aesthetic understanding of reality is impossible. The result is that, even when he does employ subject matter related to war or controversial contemporary subjects, such as 1970s leftism, Richter never editorializes or imposes an ideologically sanctioned reading of his work.

It comes as somewhat of a shock then to find Richter dealing so directly with recent cultural memory in his 18. Oktober 1977. Its form of address directly presents viewers with an empathic relationship to a painful event in West Germany's recent past. I would like to propose that the 18 . Oktober 1977 series of Richter's photopaintings (the term he uses to describe the representational paintings that he creates based on photographic sources) serves to demonstrate the difficulty that contemporary artists face in representing memories; further, Richter's signature blurred representational effect in these paintings becomes a particularly effective pictorial strategy, evoking as it does the moment of doubt between forgetting and remembrance. The ambiguity of appearing/disappearing in the painterly blur aesthetically engages with comparable experiences of memory. After a consideration of how Richter's "photopainting" technique in 18. October 1977 effectively evokes the process of memory formation, I will compare it to Richter's more recent approach to contemporary "history painting," War Cut of 2004. War Cut's abstract mode of representation and arbitrarily complex mode of composition threaten to close off the viewer from the representation of contemporary tragic circumstance, perhaps signaling the manner in which war and terror have become free-floating signifiers instead of rooted in the particular lives that make up the representations in 18. Oktober 1977.

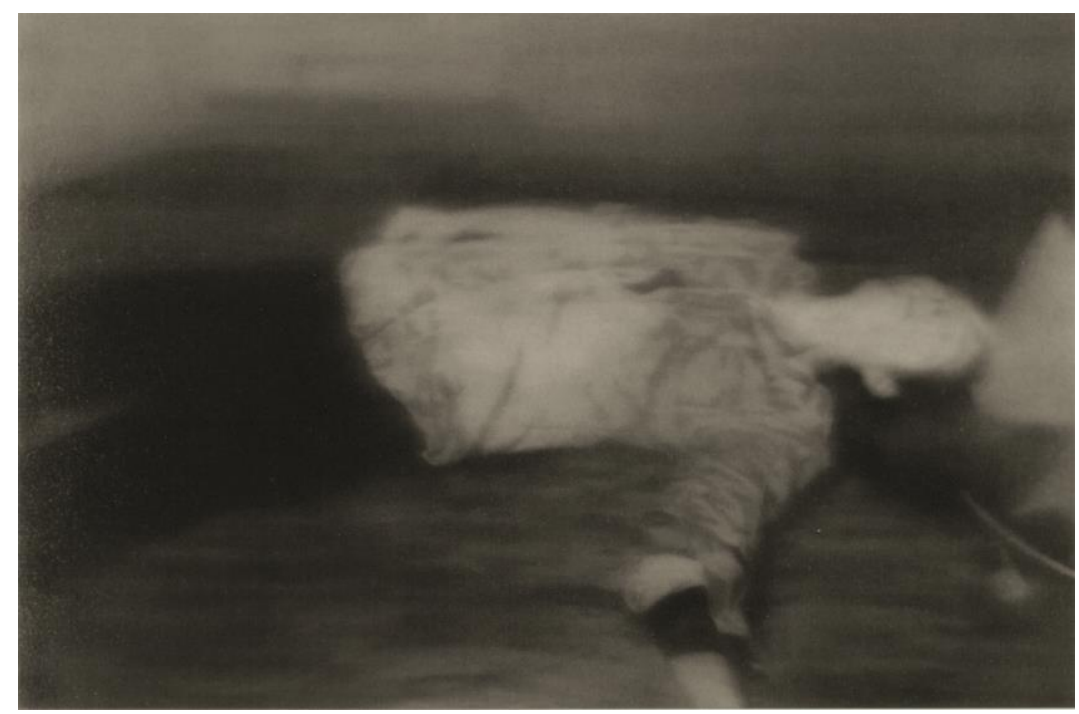

Gerhard Richter, Erschossener 2 [669-2], 1988. Oil on canvas, 100 x 140cm. The Museum of Modern Art (MoMA), New York, USA.

(C) Gerhard Richter 2017 (14072017)

The elegiac paintings that make up Richter's 18. Oktober 1977 series are arguably his most successful fusion of technique, subject and expression. In them, Richter uses a melancholic suite of grisaille photopaintings to address memories of the tragic loss of young lives. Richter derives the set of fifteen images in the Baader-Meinhof paintings from archival photographs supplied by government authorities, newspapers and family members of the Red Army Faction (although not all RAF 
participants appear in the series of paintings). This leftist group, composed of Andreas Baader, Ulrike Meinhof, Gudrun Ensslin, Jan Carl Raspe, Holger Meins, and Irmgard Möller, was responsible for a variety of German terrorist acts in the 1970s in the name of leftist political goals. The consequent arrest of these youthful revolutionaries did little to end the public fascination with them. In fact, the gruesome group suicide of its remaining members in October 1977 which occurred while the prisoners were in solitary confinement, brought out severe cultural and political fissures in West German society. This violent self-destruction, prompted by belief in an extreme political ideology, must have seemed like a thirty-year suicidal echo of the fateful choices of the wartime German state.

The title of Richter's series itself has a complicated relationship to the events it purports to represent. Despite the fact that the title, 18. Oktober 1977, gives the impression that the series covers a singular temporal occurrence, in fact, the time frame that these images cover chronologically stretches from an old student photograph of Ulrike Meinhof to three images of Meinhof after she hung herself on 9 May 1976, to images of the arrest of Meins, to images of the prison cells, cell contents, and the dead bodies of the remaining RAF after 18 October, 1977 and then finally to the image of Baader, Ensslin, and Raspe's funeral on 27 October, 1977. The paintings compress this expanded time frame into a singularly present aesthetic experience, fusing distinct circumstances, events and people into a dramatically condensed moment. Richter's temporal conflation brings to mind Walter Benjamin's evocative metaphor of the Angel of History, whose eyes are turned to the past, turning the "constant chain of events" into a "single catastrophe." But 18. Oktober 1977's temporally inaccurate title is nevertheless at odds with Benjamin's prediction that in the future the captions of photographs will "become the most important component of the shot" (Benjamin, 1931/1972: 25). Benjamin recognized that the photograph's inherent arbitrariness needs the contextualization of a descriptive title. Richter's title contradicts this necessary, descriptive function through its refusal of reliable captioning information. Further complicating our relationship to the subject is the fact that the events represented in 18. Oktober 1977 were already a least a decade old by the time Richter painted them in 1988. Richter's ten-year "delay" turned the Baader-Meinhof events into a less particular political memory. At this temporal remove, the immediately pressing details of contemporary memory fell away to reveal the story's tragic core. The sculptor Richard Serra once commented on Richter's ability to achieve "much feeling ... in [a] dispassionate way" (Storr, 2003: 203) ${ }^{2}$ Certainly Richter's technique is to be credited for this effect; but the choice to delay his artistic response by a decade also provided the emotional distance necessary to present these images as monumental rather than as a contemporary call to arms.

An illustrative contrast to Richter's "delay" is Odd Nerdrum's immediate artistic response to the same subject in his painting The Murder of Andreas Baader (1977-78). ${ }^{3}$ Nerdrum's work is everything Richter's is not. It is melodramatic, sensationalistic, one-sided, and manipulative. In contrast to Richter, Nerdrum created his work in the year of Baader's death and employed the pleading pictorial techniques and Baroque lighting of Caravaggio's Crucifixion of St. Peter and of Jacques Louis David's Death of Marat in the service of his blatantly ideological reading. Nerdrum's painting bathes Andreas Baader in a glowing sacred light as a sacrificial Christ-like figure being murdered by state agents in the dark confines of Stammheim prison. Explosive, expressive, dramatic and overwrought with physical and emotional turmoil, one cannot imagine a more polar opposite to Richter's pensive and restrained series.

Ironically, Nerdrum's greater theatricality and action seem to do less to engage the viewer or to elicit sympathy for the victim than Richter's more emotionally circumspect approach, a surprising point considering that Nerdrum's political message of victimization is clearer. Richter's interest in the RAF arises from the complex personalities and commitments of that group and the conflicting evidence about what actually happened. The collision of youthful idealism and pessimism, the selfvictimization of the prisoners and the resultant cultural regret and loss are evoked rather than didactically employed. The chronological delay and historical distance of 18. Oktober 1977 from its depicted events further draws out viewers' responses by one's difficulty remembering the particular details of the events. Richter thereby incorporates the active cognitive process of

\footnotetext{
2 Serra to Michael Kimmelman, "At the Met and the Modern with Richard Serra: One Provocateur Inspired by Another," The New York Times (August 11, 1995): C 26; cited in Storr, (203).

${ }^{3}$ See the image at https://en.wikipedia.org/wiki/The_Murder_of_Andreas_Baader (accessed 10 July 2017).
} 
forgetting/remembering, almost as if the blur is a representation of trying to remember. This strategy avoids mere reaction. We read tragic fate, murderous and suicidal, into these images of youth who are so fervently possessed by ideology.

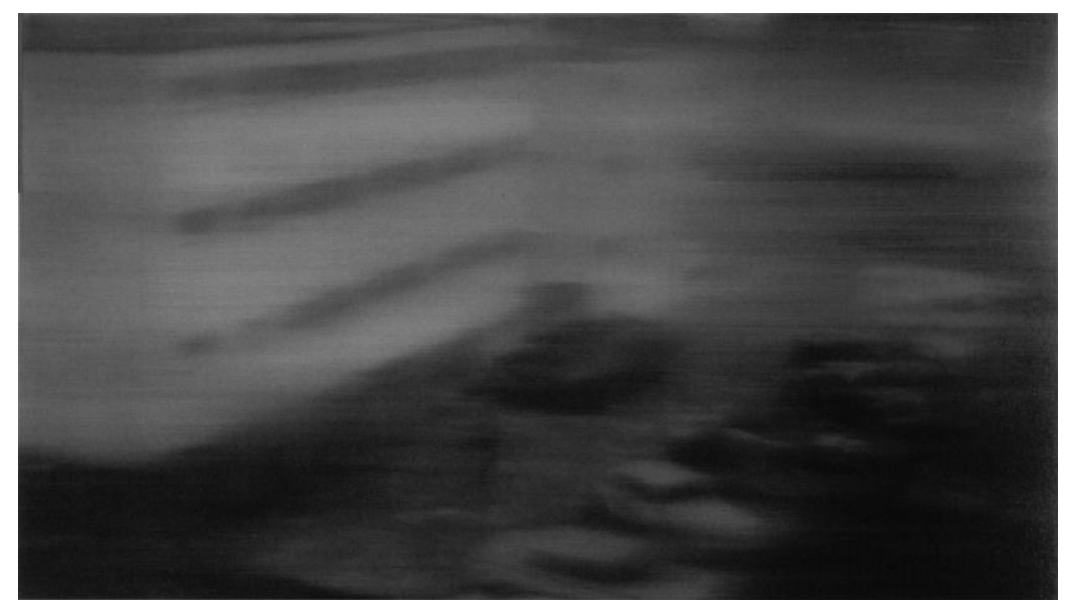

Gerhard Richter, Festnahme 1 [674-1], 1988. Oil on canvas, 92 x 126cm.

The Museum of Modern Art (MoMA), New York, USA.

(C) Gerhard Richter 2017 (14072017)

There seem to be two primary criticisms one could make of Richter's sympathetic and slightly romantic "blurred" treatment of the Baader-Meinhof subject. First, leftist critics note how Richter's lack of focus occludes the details that a viewer needs to remember and then to interpret the nature of historical fact. The obfuscation of historical detail is said to thwart our ability to be an active political agent. Without adequate and accurate information, we cannot act. Richter has failed in his political duty to provide information or experiences that would allow one to intervene in contemporary culture and politics. The works could therefore be interpreted as Romantic obfuscations of facts rather than critical statements, eulogies rather than battle cries. Richter turns his back on Benjamin's 1931 description of the task of the photographer who, as "descendant of the augurs and haruspices," should "uncover guilt and name the guilty" (Benjamin 1931/1972: 25). ${ }^{4}$ Secondly, Richter's pictorial softening of the brutal photographic details of the corpses runs the risk of aestheticizing death, of turning death itself into an object of aesthetic contemplation and beauty. Such an aestheticization runs the risk of fostering either a defeatist political attitude about the potential for revolutionary change or a glorification of suicidal death as a means to achieve political ends.

In either case, Richter's characteristically blurred photopaintings are politically problematic because they smooth over the rough edges of history and death, allowing the viewer to be a passive recipient of aesthetic experience and bathing in reflection rather than being spurred on by outrage to revolutionary action. One critic more sympathetic to the aims of the RAF than Richter wrote that, "Revelation is needed, not mourning or the over-painting of that which remains unclear, but the

\footnotetext{
${ }^{4}$ Benjamin Buchloh, who flatly declares that the Red Army Faction members were assassinated, desperately wants to read Richter's series as participating in the revolutionary role Benjamin assigns to the photographer. But his is an ill-fitting interpretation, especially since Richter is ambivalent about the motives of the group, admitting even that the prisoners likely died by their own hand. Because doctrinaire leftist criticism views historical circumstance as the cumulative effect of structural conditions, any representation, especially that of leftist political subject matter, must necessarily reveal the subjection of revolutionary hope at the hands of the systemic and oppressive use of instrumental power. As Buchloh puts it:

[Materialism] understands the process of history as no longer being the isolated results of powerful subjects' deeds or as a series of events, but as an agglomeration of numerous interlinked, long- and short-term, structures and interaction amongst the largest possible number of social subjects. This model is, of course, also the history model advocated by historians at the Annales School in France, and was first formulated in the late 1920s by Lucien Febvre and Marc Bloch (Buchloh, 1998: 53).

By this measure, Richter's works fail to provide the appropriate context for this leftist revolutionary group. Instead of focusing on the instrumental power of the capitalist state crushing revolutionary hope, Richter's myopically focuses on the (self-destructive) actions of individuals.
} 
opening of wounds. Not clemency... Art has to confront these distortions of reality, should reveal not conceal" (Heyme 1989, 15) Is Richter's technique of blurring thus a painterly analogue to what Adorno calls the "decaying aura as foggy mist" of the culture industry? ${ }^{5}$ Does Richter's seeming occlusion of the specifics of historical memory in the painterly blur pull a gauzily romanticized scrim over the brutal workings of the state?

Rather than providing cover for state operations, the paintings' indistinctness thematizes the problematic equating of images and memory; it suspends the assumption that images are transparently commemorative and mnemonic even as it engages our desire to use them so. The original photographic sources for Richter's paintings are filled with many more anecdotal details than his final paintings convey (such as identifiable clothing style, particular items in the prisoner's cells, and expressions on the prisoners' alive or dead faces). By occluding these particularities and through his frustration of the viewer's desire for the photograph's absolute optical clarity and visual supremacy, Richter presents the dilemma that, "our sense of sight causes us to apprehend things, but at the same time restricts and partly precludes our apprehension of reality" (Richter 1995:64) ${ }^{6}$ Richter's BaaderMeinhof paintings thereby make a point of their incompleteness and through their illegibility preclude conceptual coherence. As Robert Storr suggests, these works speak an "anguished uncertainty about historical truth as well as of a principled refusal to take sides in a contest of destructive absolutes" (Storr 2003: 6). Particularly telling as to Richter's ideological neutrality, is his decision to sell the 18 . Oktober 1977 series to the Museum of Modern Art in the United States, where its mostly American audience would necessarily be less informed of the historical particularities of its subject matter. Nevertheless, Richter is comforted by the thought that viewers will not treat the works as political illustrations. Richter's trademark muted grisaille counters the $20^{\text {th }}$ century tendency to view history through a stark, binary, ideological, black-and-white filter.

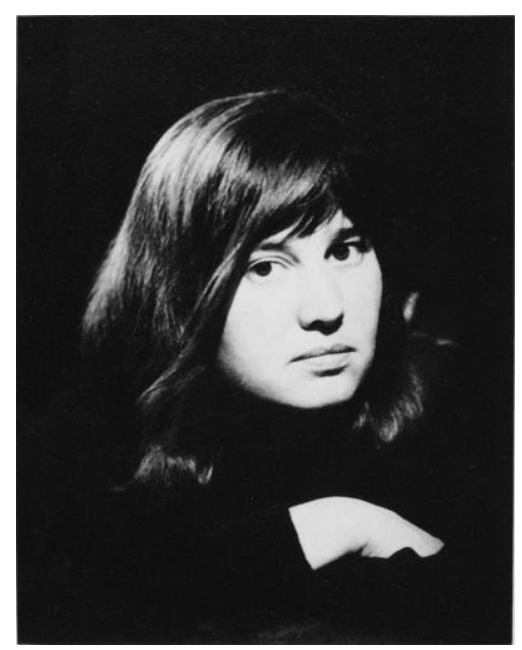

Left: Jungendbildnis source image.

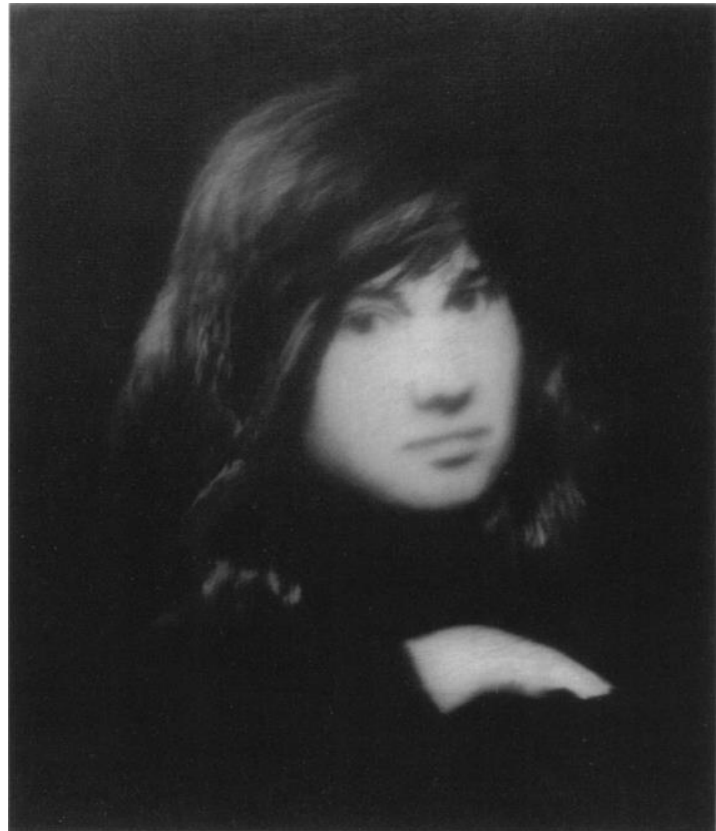

Right: Gerhard Richter, Jungendbildnis [672-1], 1988. Oil on canvas, 67 x $62 \mathrm{~cm}$. The Museum of Modern Art (MoMA), New York, USA.

(C) Gerhard Richter 2017 (14072017)

\footnotetext{
${ }^{5}$ The full quote is: “Adopting Benjamin's designation of the traditional work of art by the concept of aura, the presence of that which is not present, the culture industry is defined by the fact that it does not strictly counterpose another principle to that of aura, but rather by the fact that it conserves the decaying aura as a foggy mist. By this means the culture industry betrays its own ideological abuses" (Adorno, 2001: "Culture industry reconsidered," (1963: 101-102).

6 "Perhaps the Doors, Curtains, Surface Pictures, Panes of Glass, etc. are metaphors of despair, prompted by the dilemma that our sense of sight causes us to apprehend things, but at the same time restricts and partly precludes our apprehension of reality" (Richter, "Notes, 1971", 1995: 64).
} 
The assumption at work in most writing about Richter's "blur" is that it obliterates detail. But one might just as easily propose that these pictures enact an image's/memory's appearance rather than disappearance. Richter certainly diffuses the source images for 18. Oktober 1977 in a fog of indistinctness by brushing over their original painted transfer. But might the resulting image and its state of vagueness be a staging of revelation and appearance, of the subject's fragile, yet positive presence? Why is it that we almost automatically read this indistinctness as a negation? Is the veracity of the source photograph's profuse details somehow readable or even felt behind that painterly veil?

In its evocation of the appearance of the image/memory, Richter's series might feel closer to the Veil of Veronica or the Shroud of Turin than to the banal documentary photos that they derive from. More palpably substantial than photographs, the image within Richter's paintings seems to hover in an indeterminate space just beyond our perceptual reach. Photopaintings seduce with their painterly, smoky, sfumato atmosphere even as they complicate and frustrate this sensual experience by continually staging the inaccessibility of its photographic source. Whetting a desire for the visual omnipotence, complete access, and immediate apprehension of the photograph, Richter perversely employs painterly effects that hinder and frustrate that desire. ${ }^{7}$

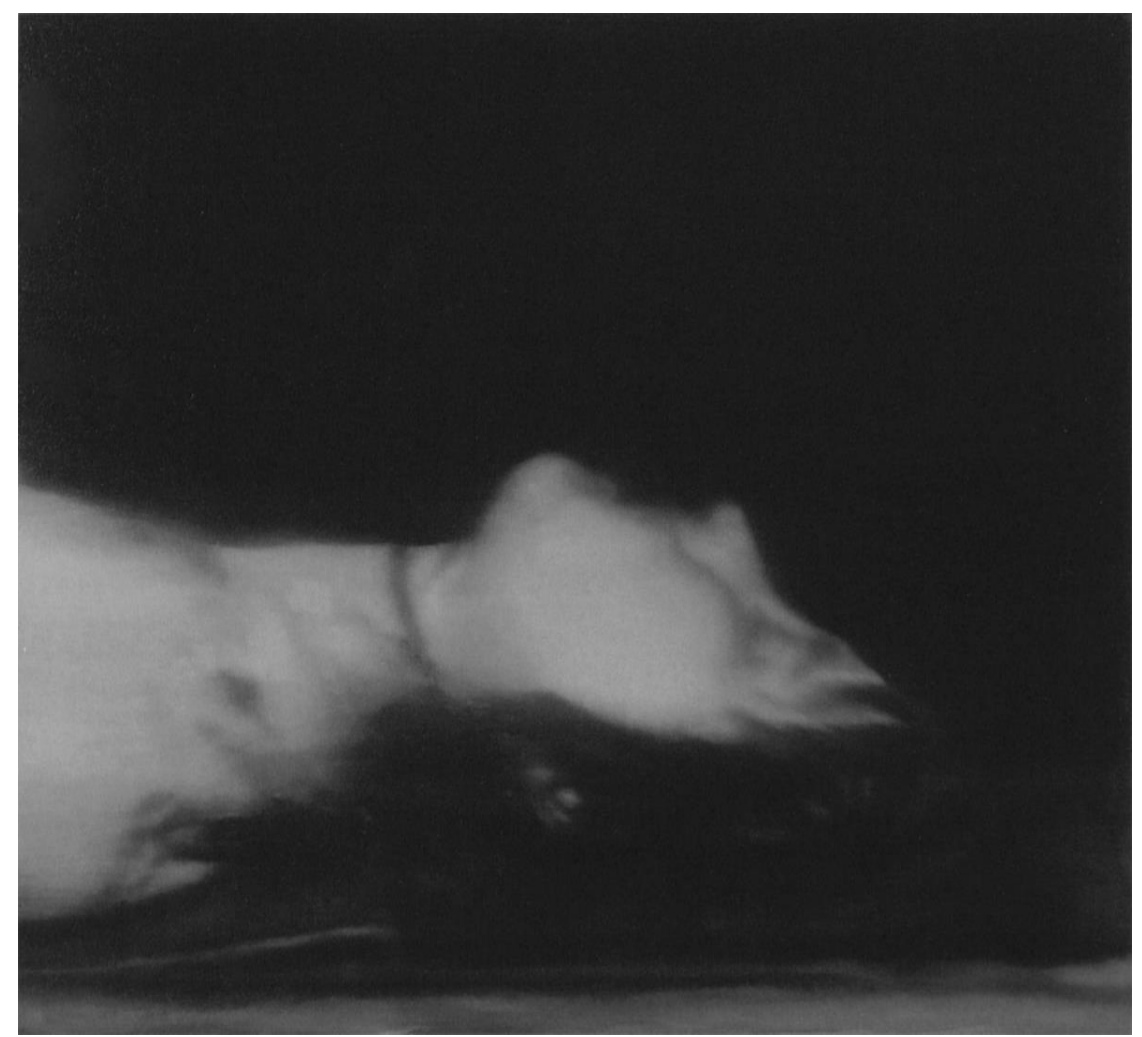

Gerhard Richter, Tote [667-2], 1988. Oil on canvas, 62 x 62cm. The Museum of Modern Art (MoMA), New York, USA.

(C) Gerhard Richter 2017 (14072017)

Perhaps the one thing that Richter's blurry images openly deny by their un-clarity is access to what Roland Barthes calls the punctum of the photograph. Punctum and studium are the two terms Barthes uses to determine the particularly compelling character of the photographic image in his Camera Lucida (1980). The punctum is the seemingly insignificant detail that pierces through the general field of human interest (the studium), with a "sting, speck, cut, little hole." "It "is that accident

\footnotetext{
${ }^{7}$ Stephan Germer argues that Richter's "content is only arrived at by means of a negation of form, form only as a negation of content: which means that the whole project or representation is called into question" (Germer in Rainbird and Severne 1992: 26).

${ }^{8}$ Storr draws a number of interesting parallels between Barthes and Richter in his illuminating book. And, even though my sympathy with his position on Richter is obvious, I am using Barthes's ideas about the studium and
} 
which pricks" the viewer with the poignant evidentiary eruption of the real (Barthes 1981: 26-27). Richter's visual reference to the photographic source in his photopaintings causes the viewer to reflexively search for the image's punctum, which his paintings are not sharp enough to reveal. This invitation/denial or seduction/refusal is one of the strongest dynamics of this painterly fugue. Even as they steal the "evidentiary" power of the photograph, the paintings refuse the photograph's particularity. In fact, Richter's paintings are closer in spirit to the diffuse romanticism of Gertrude Kasebier's photographs. Where Kasebier pulled photography towards painting through her choices of subject matter and her "painterly" handling of tone, Richter employs "painting as a means to photography" (Storr, 2003: 27).

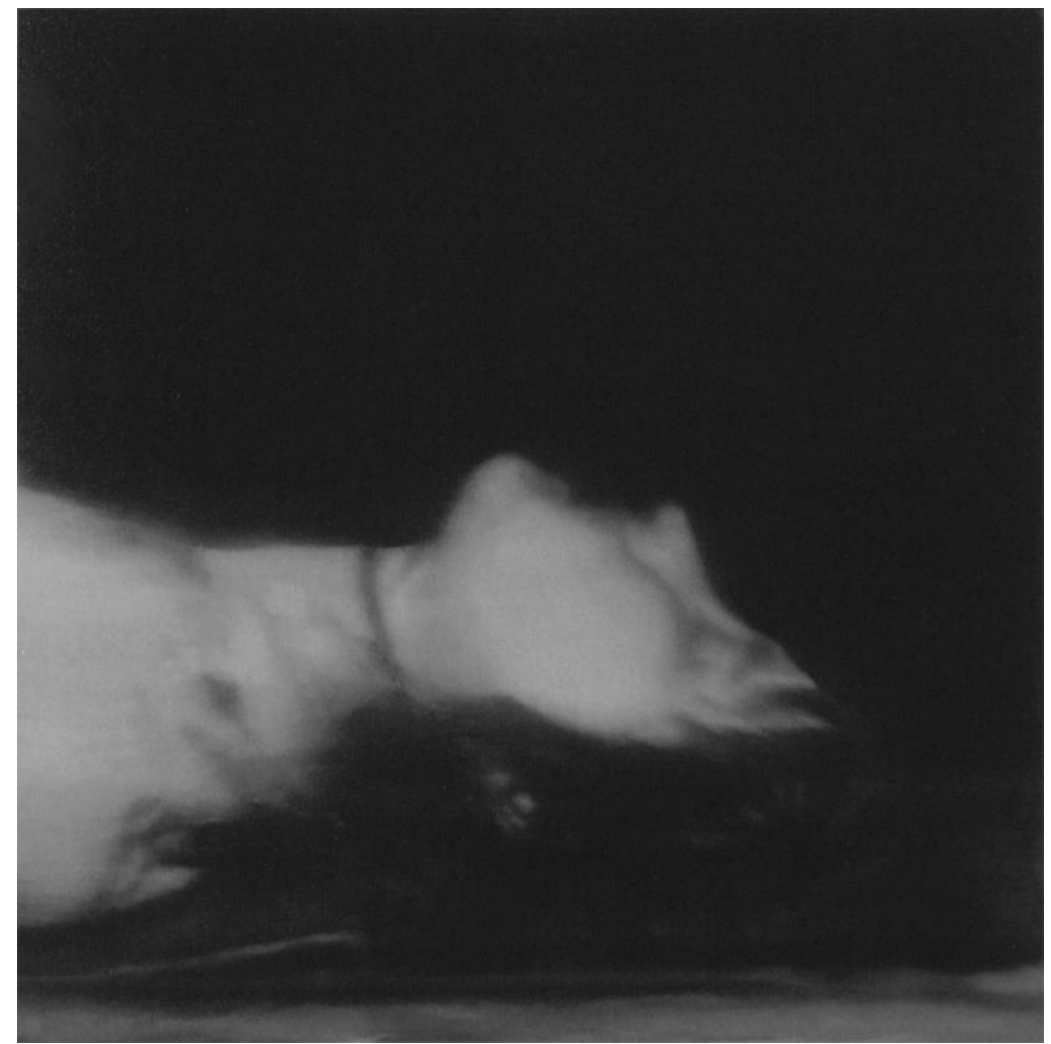

Gerhard Richter, Tote [667-3], 1988. Oil on canvas, 35 x 40cm, 1988. The Museum of Modern Art (MoMA), New York, USA.

(C) Gerhard Richter 2017 (14072017)

Richter seems to want to draw out of the photograph an experience of authenticity, of immediacy, and of cross-temporal connection; ironically, he does so by obscuring the very auratic details (the punctum) that our eyes instinctively seek in the photograph. Richter is aware, as is Barthes,

punctum in a quite distinct manner. Storr suggests Richter transfers the effect of the punctum to the manipulations Richter employs on the image, where I am suggesting the shift is toward a process of apprehension. Here is one place where Storr elucidates his application of Barthes: "Barthes's distinction between what he calls the photograph's studium (its dominant image and overall scope) and the photograph's punctum (the unique, even incidental detail that stops the eye, pricks the mind, and captures the imagination) is also provocative insofar as Richter's brushy re-presentation of photographs tends to obscure the dominant characteristics of the image (studium) or render it generic - a portrait, a landscape - even as it exaggerates existing anomalies (puncta) within the image. The latter occurs often (as an awkward gesture or a byproduct of painterly accents and erasures) and we may take Richter at his word when he says that he turned to photography "not to use it as a means to painting but use painting as a means to photography" not, that is, to imitate photographs but to remake them in paint" (Storr 2003: 27). There is a quite different application of Barthes terms at the hands of Benjamin Buchloh, who suggests their potential in relation to Richter's Atlas project Buchloh notes that where the first Atlas pages contain clear snapshot pictures when Richter introduces photos of the Holocaust into his archive there is a shift to blurry images. Buchloh suggests that these images are the punctum that interrupts the studium of banality that is the character of the rest of Richter's Atlas. 
of the way in which the visual plenitude of photographs can block memory as much as they can facilitate it. The photograph becomes a "counter-memory" (Barthes, 91) where "you don't remember actually what happened, you remember the photo" (Richter in Storr 2003, 37). ${ }^{9}$ Instead of providing memories for the viewer through clear substitutionary images, relying on the details of the subject to speak to the viewer, Richter creates an aesthetic experience of memory/remembering through a perceptual experience of the image's materialization in subjective apprehension. Siri Hustvedt suggests that Richter's photopaintings "conjur the feeling of remembering itself, which is always a clouded or faded version of what was once seen" (Hustvedt 2002: 56).

But Richter's evocation of memory loss through indistinctness is also dialectically twinned with an evocation of the emergence and re/appearance of the contents of memory by the apparent emergence of the image in paint. Richter's photopaintings therefore not only occlude and deny access to images but also reveal and enact their disclosure. As Richter notes, paintings cannot be "blurry"only photographs can. Instead of allowing the particular details of these images to function as punctum, Richter shifts the viewer's experience to an awareness of the conflation of memory and perceptual apprehension. In their suppression of detail, the 18. Oktober 1977 images enact the process of dredging up memories.

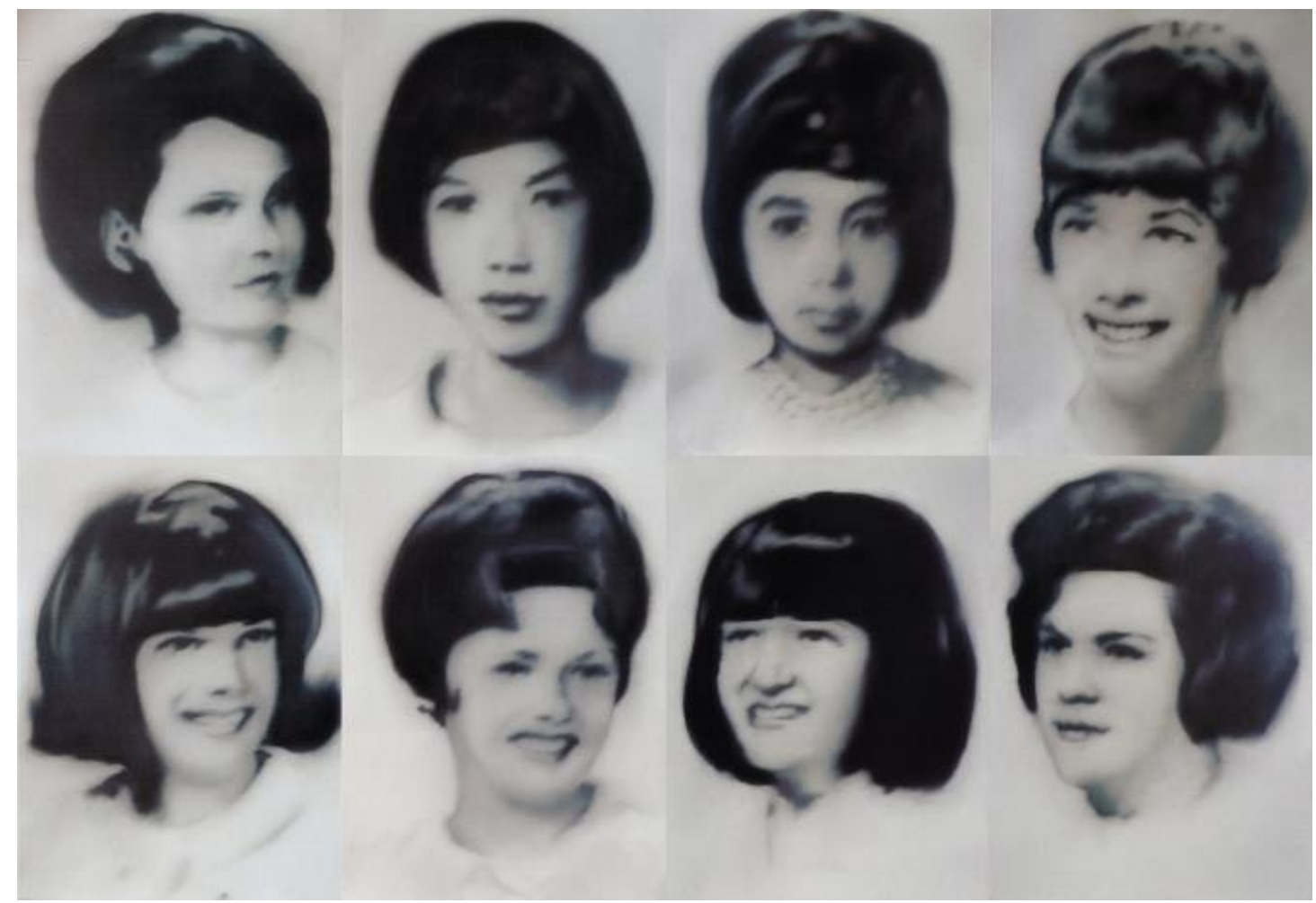

Gerhard Richter, Eight Student Nurses [130], 1966. Oil on canvas, eight parts, each 95 x 70cm.

(C) Gerhard Richter 2017 (14072017)

The tragic subject matter of many of Richter's photopaintings, such as Eight Student Nurses (1966), representing the nurses murdered by Richard Speck, the painting of the murdered prostitute Helga Matura or Richter's Youth Portrait painting of Ulrike Meinhof, become evocations of Barthes' second, less frequently invoked, form of the photographic punctum, the stigmatum. The stigmatum is not "of form but of intensity;" "it is Time, the lacerating emphasis of the noeme (the "that-has-been") (Barthes, 80). In a striking parallel to Richter's images of the soon-to-be-dead Baader-Meinhof prisoners, Barthes even uses the photograph of a criminal taken just before his death to illustrate the character of this second form of punctum. In 1865, Alexander Gardner photographed young Lewis Payne, who was awaiting execution for the attempted murder of United States Secretary of State W.

\footnotetext{
${ }^{9}$ Barthes: "Not only is the Photograph never, in essence, a memory (whose grammatical expression would be the perfect tense, whereas the tense of the Photograph is the aorist), but it actually blocks memory, quickly becomes a counter-memory" (Barthes: 91).
} 
H. Seward. What Barthes finds searing about this picture is not the particular detail he had earlier searched out, but the observation that Payne "is going to die...this will be and this has been." As the viewer of this fate, Barthes becomes a prophet of an already-fulfilled destiny, an observer of the subject's "anterior future" (Barthes, 95-96).

In Payne's photograph our superior "prophetic" knowledge of the subjects' final fate only serves to demonstrate our impotence to change it. Richter refers to this pathos in his paintings as the "injured" beauty of the ill-fated subjects of the 18. Oktober 1977 series. This second form of punctum is the integration of our experience of the image with our god-like knowledge of the fate awaiting the subjects in their future. It is a pathos evoked when paging through a family photo album and discovering innocence in pictures where we now possess knowledge of what is to come.

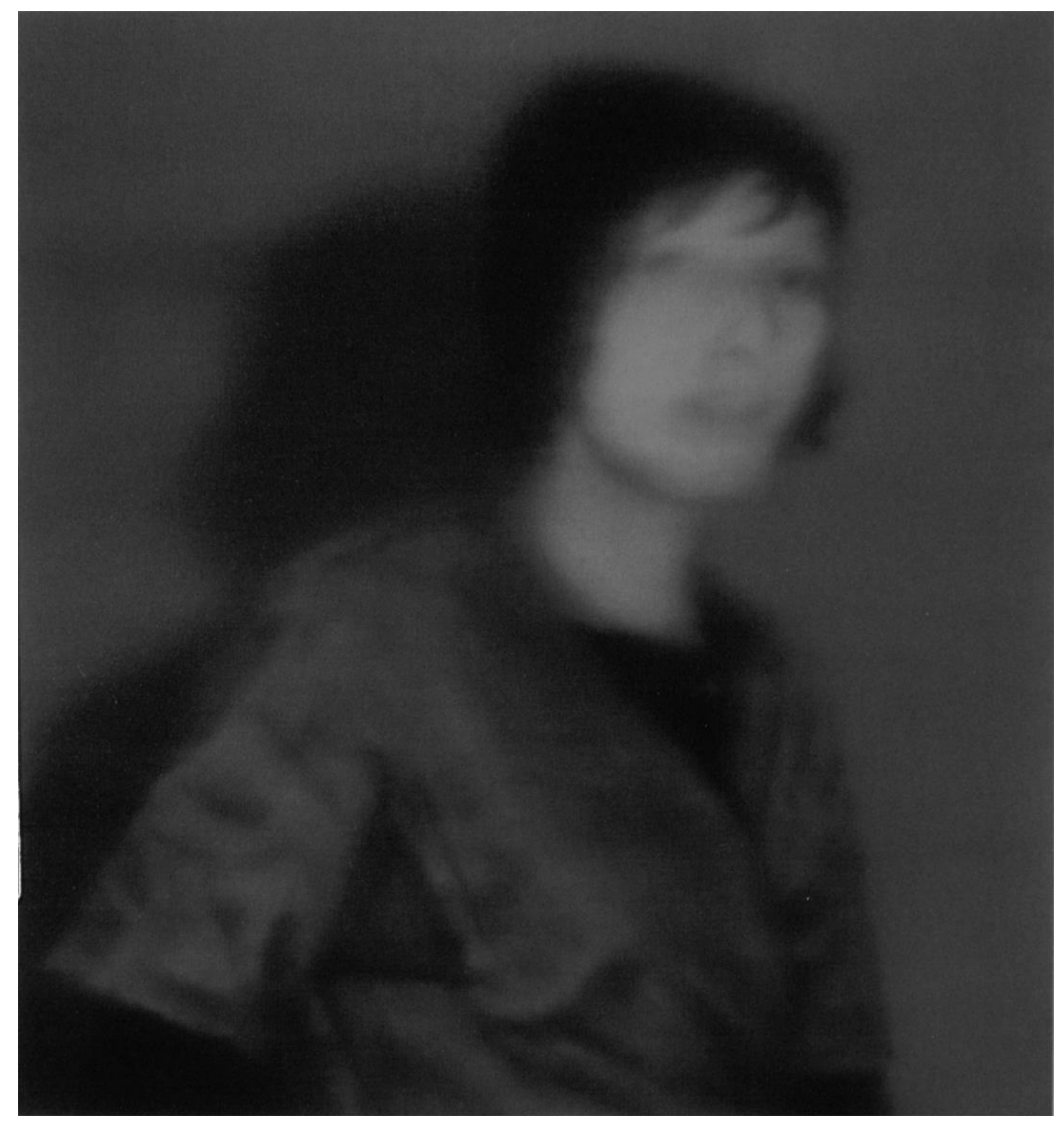

Gerhard Richter, Gegenüberstellung 1 [671-1], 1988. Oil on canvas, 112 x $102 \mathrm{~cm}$. The Museum of Modern Art (MoMA), New York, USA.

(C) Gerhard Richter 2017 (14072017)

The veil that Richter pulls across the image seductively allures us into the picture's visual embrace while simultaneously demonstrating our inability to grasp a reliable image of the past. Richter's diffusion of the image details loosens the ideological straitjacket of his subjects, putting the viewer in touch with the terrorists' humanity, pointing to the tragic power of all ideological delusions. Richter's project seeks to resuscitate the relation between painting, photography and cultural memory without espousing a naive pretence of the capability of any medium to adequately represent history.

Richter's technology of photopainting mitigates the way in which photography, pandering to our acquisitive visual desire, actively occludes memory through its high level of convincing detail. Richter's photopaintings employ the density and materiality of paint to make the process of memory into an object of aesthetic apprehension. If feeling in the postmodern world, the deja-senti, reaches us as something "already felt, releasing us from responsibility and sparing us from the burden of a subjective and personal first-hand experience," as Mario Perniola suggests (Perniola 1995: 28), then Richter's photopaintings of 18. Oktober 1977 re-enliven our experience of these subjects using the already-seen, the long-ago-felt, and the used-up, to evoke the here and now. However, if Richter reanimates the resting dead subjects, he does so not to move, as Barthes says, "toward the fantasy of a 
praxis, but [instead to move] toward the absolute excellence of a being, body and soul together" (Barthes, 59). Perhaps it is the manner in which Richter's series faithfully renders the experiences of the postmemory generation of Germans that makes it so powerful. As Hirsch notes,

\begin{abstract}
Postmemory is not identical to memory: it is "post;" but, at the same time, it approximates memory in its affective force. [Eva] Hoffman describes what was passed down to her thus: "Rather, I took in that first information as a sort of fairy tale deriving not so much from another world as from the center of the cosmos: an enigmatic but real fairy tale. ...The memories - not memories but emanations - of wartime experiences kept erupting in flashes of imagery; in abrupt but broken refrains" $(6,9)$. These "not memories" communicated in "flashes of imagery" and "broken refrains," transmitted through "the language of the body," are precisely the stuff of postmemory (Hirsch, 2008: 106).
\end{abstract}

Hirsch further argues that the photograph, whose strength Richter recognizes and adopts, is the postmemory medium par excellance:

[P]ostmemorial work, I want to argue -- and this is the central point of my argument in this essay -- strives to reactivate and re-embody more distant social/national and archival/cultural memorial structures by reinvesting them with resonant individual and familial forms of mediation and aesthetic expression. (Ibid.)

More recently, instead of photopaintings, Richter has employed abstraction to represent the Gulf War. $\mathrm{He}$ also seems to have shifted the use of the photopainting style for more exclusively personal and intimate images of family and friends. Richter's shift in strategy raises the question as to whether even the indistinct form of historical representation found in his photopaintings seem no longer viable as a technology of contemporary memory.

\title{
3. War Cut: Systematized Arbitrariness
}
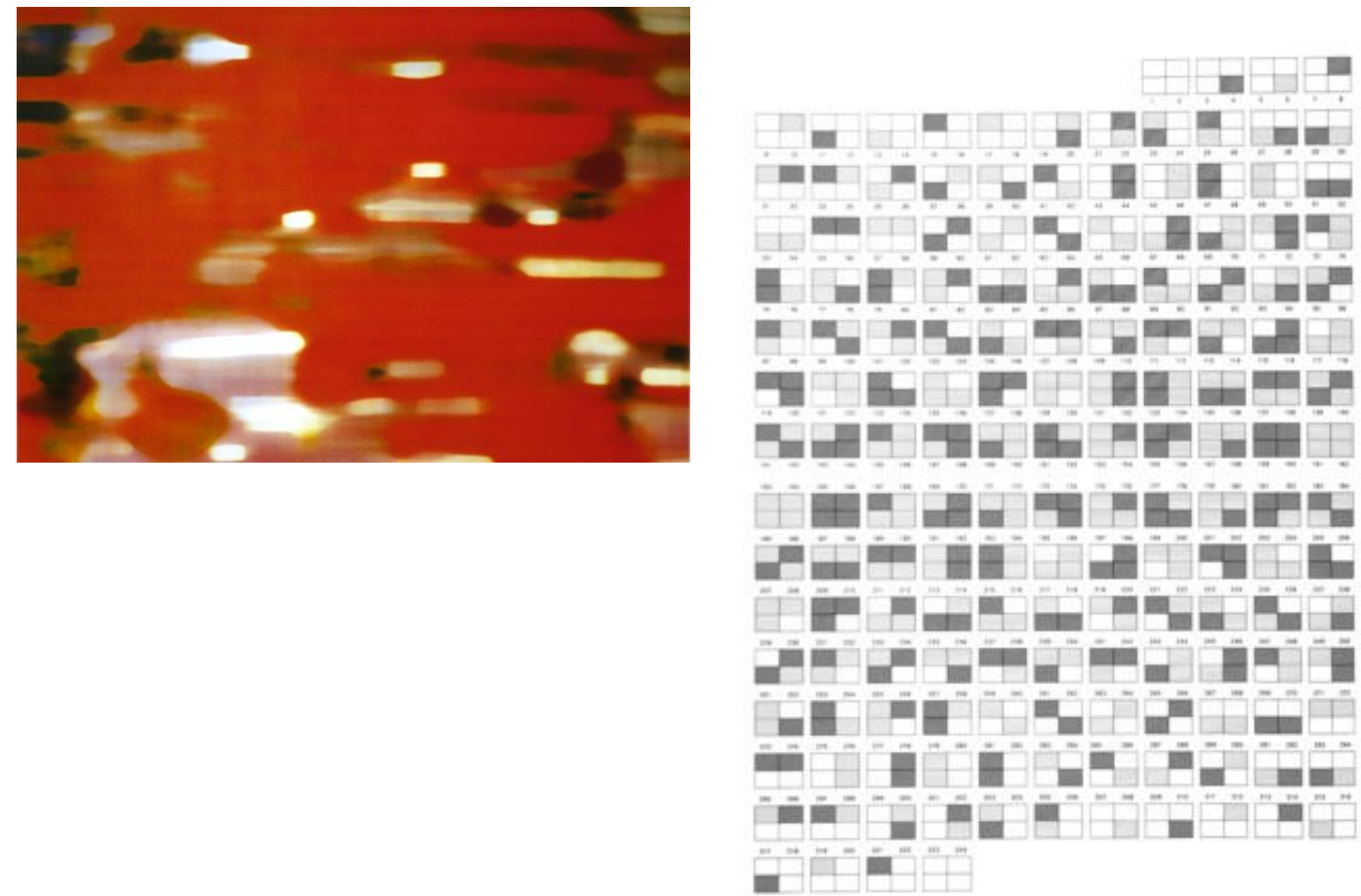

Left: Gerhard Richter, War Cut, 2004.Fragment of Abstraktes Bild (648-2), p. 127.

(C) Gerhard Richter 2017 (14072017)

Right: Gerhard Richter, War Cut, 2004. Diagram of book layout.

(C) Gerhard Richter 2017 (14072017) 
Richter's 2004 War Cut brings his earlier concerns about the unreliability of memory and the problematic representation of history to a fevered pitch in his project's arbitrary application of conceptual rigor. With an incongruous combination of Teutonic precision and indiscriminate arrangement, War Cut juxtaposes free-floating journalistically-derived text blocks and abstract images.

In a 2004 interview with Richter about his artist-book War Cut, Jan Thorn-Prikker notes how War Cut is composed of 216 photographic close-ups of Abstraktes Bild (Catalogue Raisonné: 648-2, heretofore referred to as 648-2). Painted in 1987, 648-2 is now in the collection of the Modern Museum of Art in Paris. Richter arranges these fragmentary close-ups with an eye to what he calls "aesthetic criteria," that is, according to the direction of the brushstrokes, "colors, structures and other characteristics" (Thorn-Prikker, 2004: n.p.). The photographic close-ups of the painting fragments are then (mostly) randomly juxtaposed with 155 transcriptions of journalistic texts about the Iraq war from the March 20 and 21, 2003, Frankfurter Allgemeine Zeitung. ${ }^{10}$

Dedicating each page to single or paired images and an equal amount of space to the texts, the book alternates between details of the vibrant and strident colors of Richter's painterly strokes and the monochromatic blocks of text. The texts' subjects are varied, such as the question of Jewish influence on American foreign policy to Turkey's role in the Iraq war. Richter also sets up a mirroring visual effect over the book's 324 pages - where the images and text on the pages from the beginning and end, moving toward the middle, occupy opposing positions on the pages, culminating at the book's center where the mirroring effect meets. However, this visual mirroring is not at all obvious unless one decodes it via a comprehensive visual index provided in the book.

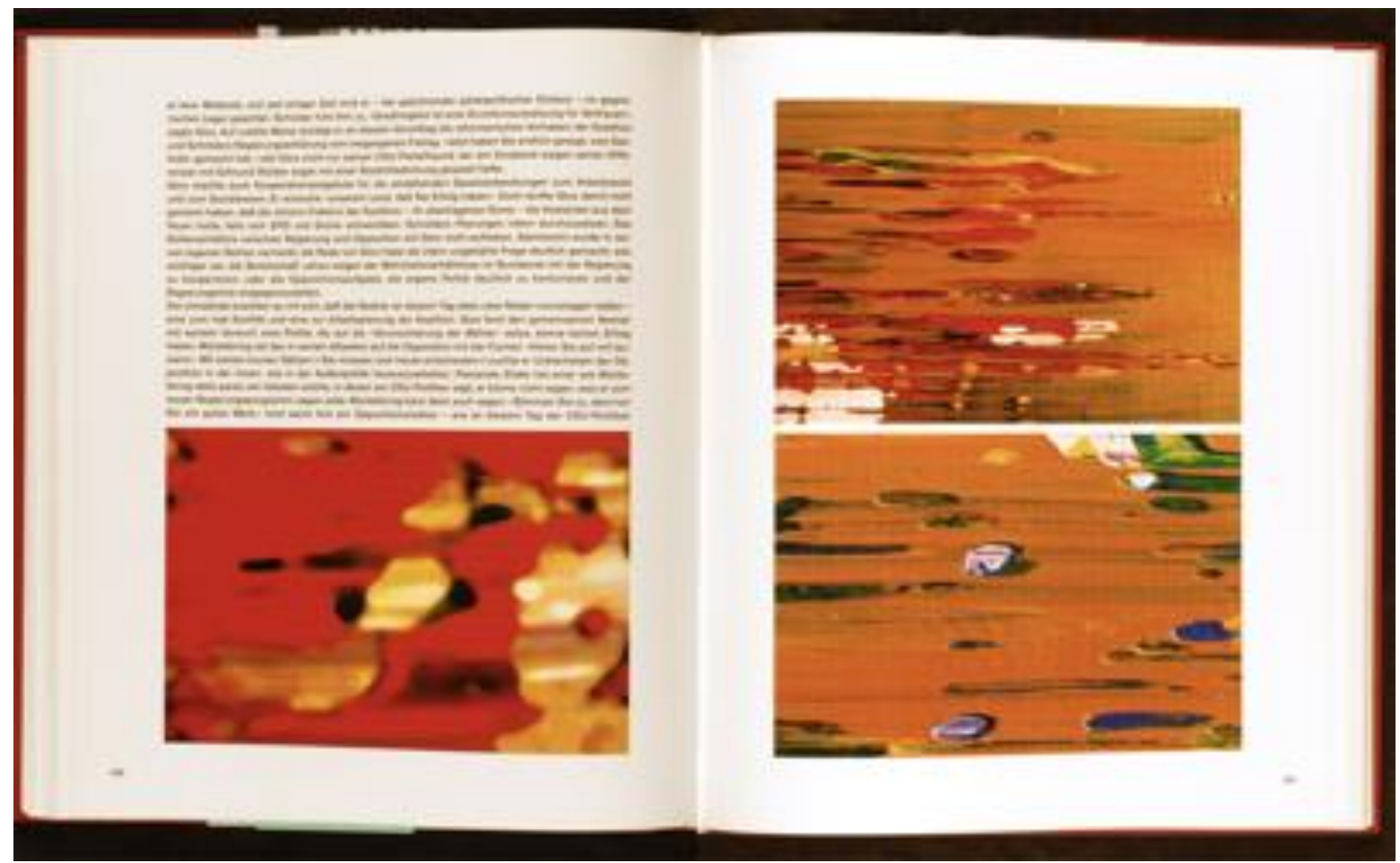

Richter, War Cut, 2004. Text and photos of painting fragments, (pp. 169-170).

(C) Gerhard Richter 2017 (14072017)

Viewed individually or when compared with the text directly opposite them, the close-up images have a compelling directness and immediacy. The painterly details appear as microscopic structural parallels of Richter's full-sized abstract paintings, as if the whole source painting itself had been created from the details of yet another painting. Richter's compositional conceit creates a

10 I say "mostly" because Richter does say that a few of the random combinations of image and text did not work: "most did fit together, and only a few inappropriate or banal conjunctions had to be changed" (ThornPrikker 2004). 
dizzying effect, where one can imagine that the re-photographing of the source painting's details could lead to an endless succession of paintings made from the details of other paintings. Alternating between clear photographs of surfaces laden with thick paint and blurry images of amorphous fields of color, the photo-details give the viewer a kind of absolute visual access to the structure of $648-2$ and yet they do so without revealing anything about the source image at all; they reveal hidden structure while at the same time obscuring overall coherence.

Unlike $\mathrm{x}$-rays or other technological photographic interventions that serve to validate an artist's working method or to verify a work's genuineness, Richter's photo-details employ sheer arbitrariness to make the connection to the source painting more problematic rather than authentic. Thorn-Prikker suggests a reading of the photo-details of War Cut using a Rorschach-like interpretive flourish that suggests, "oil fields on fire," "pools of oil," pools of "blood," "ghosts, death heads and hideous faces."

These suggested images are not, of course, placed there by Richter or even discovered by Richter through re-photographing. Instead, they are created by the viewer's associations with the artist-prescribed theme. Richter, as noncommittal as ever, responds to such an interpretation saying, "I have nothing against that" (Thorn-Prikker 2004: n.p.).

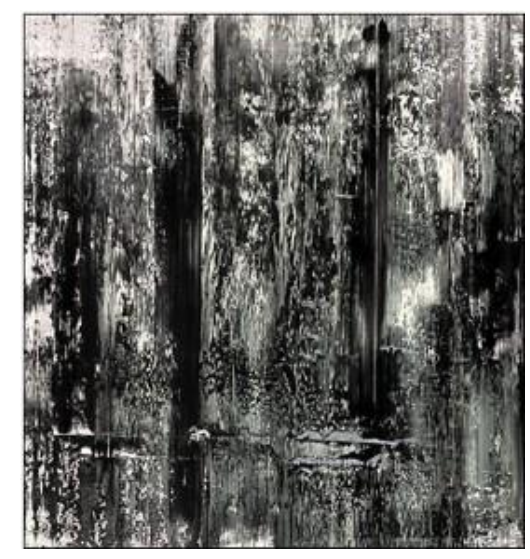

Left: Gerhard Richter, Abstraktes Bild [648-2], 1987 (Small, black and white reproduction, from War Cut, 2004).

(C) Gerhard Richter 2017 (14072017)

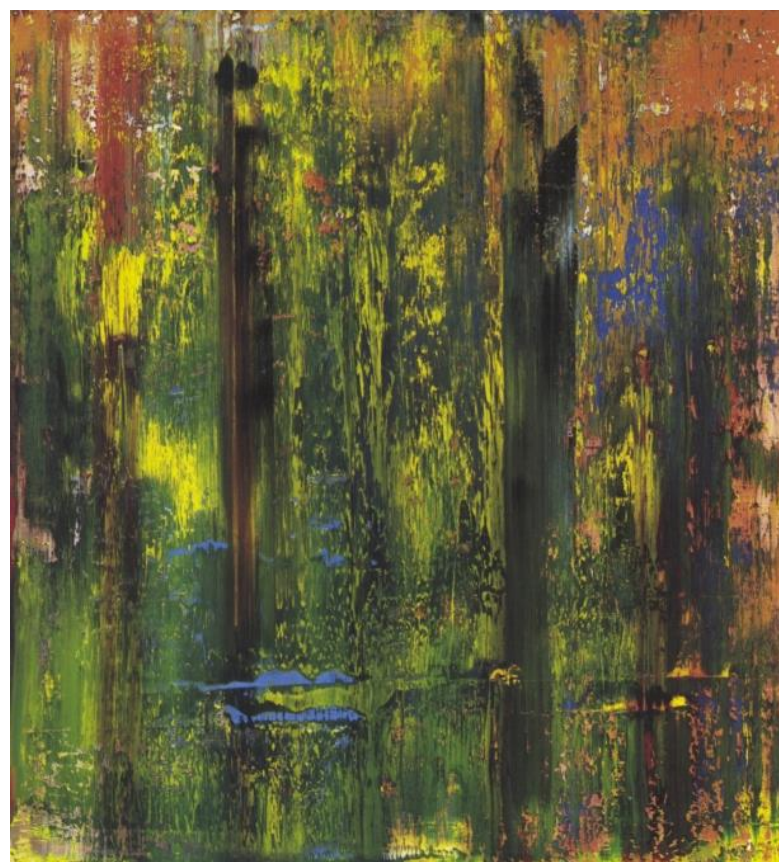

Right: Gerhard Richter, Abstraktes Bild [648-2], 1987. Oil on canvas, $225 \times 200 \mathrm{~cm}$. Musée d'art moderne de la Ville de Paris, Paris, France.

(C) Gerhard Richter 2017 (14072017)

One might expect the image details, coming as they do from an aesthetically coherent image, an abstract painting no less, to at least have a clear relationship to the whole; but even this expectation is thwarted. The source painting, 648-2, is illustrated in the back of the artist's book in such a small format and in such drab black and white that it makes the process of identifying the original location of the photo-details in the book impossible. So, instead of the photo-details adding up to a summary experience at the end of the book, allowing one to place each portion in its proper larger context, making its relative meaning as a part of the whole clear, one finds that the "whole" work is less impressive than its obsessively reproduced photo-details. Richter thereby inverts the expected hierarchy by elevating the effect of the isolated and discrete detail over the aesthetic coherence of the whole. 


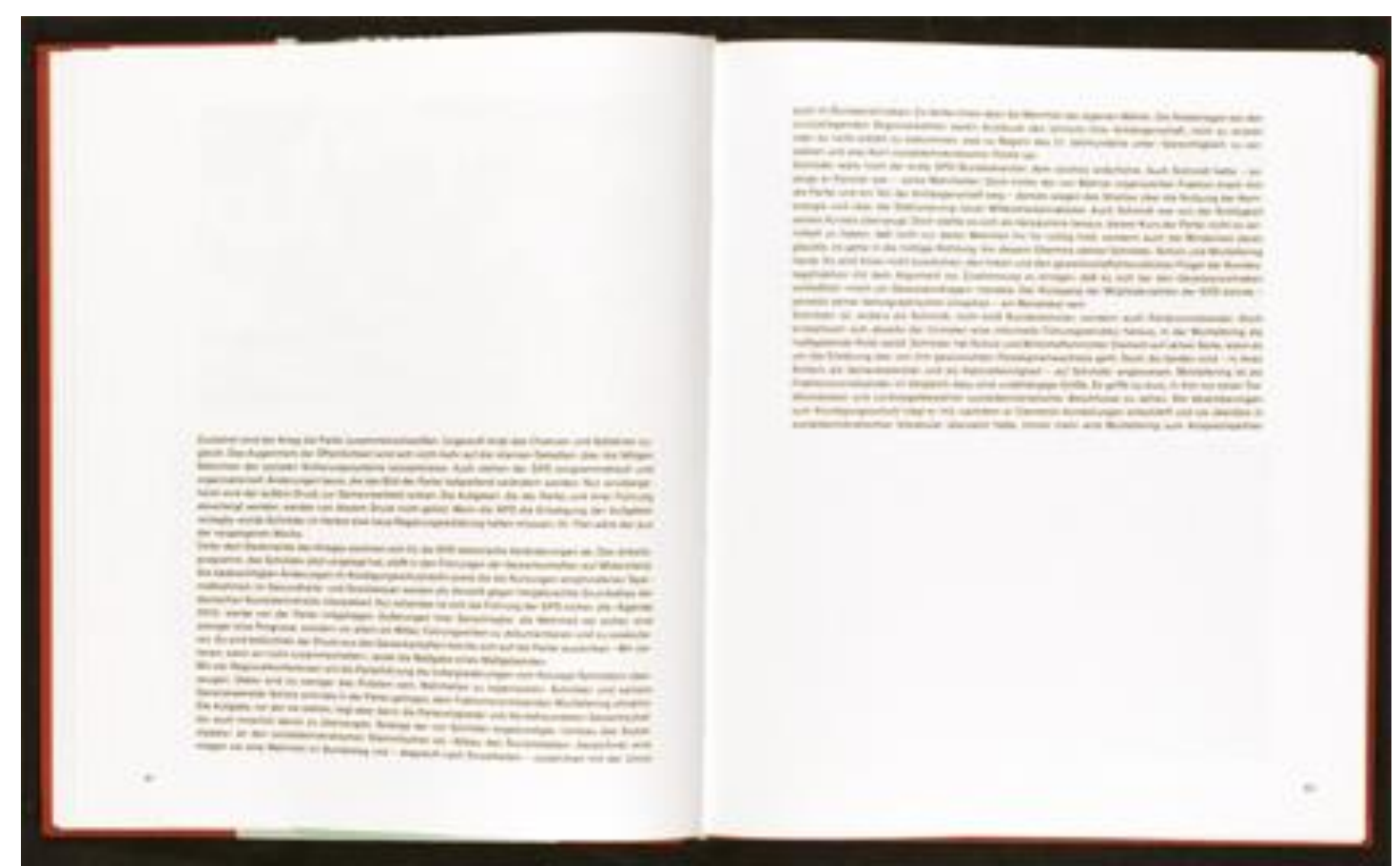

Gerhard Richter, War Cut, 2004. Text pages (pp. 61-2).

(C) Gerhard Richter 2017 (14072017)

Likewise, the distinct and coherent individual newspaper articles, which declaratively lay out the details of the war's early days, are strung together in War Cut, each new text block only signaled with a triangle. Richter described the original news reports of the war as "impotent" and "ineffectual" but found their "plain presentation of the facts" as "consol[ing]" (Of course, the same facts that consoled Richter in 2003, are now anything but consoling in light of revelations about the false premises that justified the war to begin with. The texts flout the limited editorial coherence the reader of the daily newspaper expects in its categorical types (global and domestic affairs, arts, business, lifestyle, etc.) and page layout decisions. Where the content of Richter's War Cut texts is arranged according to arbitrary criteria, the text's physical spacing is obsessively plotted.

These facts make War Cut inscrutable enough, but there is also the matter of timing. It was in 2002, well before the second Iraq war began, that Richter photographed the series of details of the then-15-year-old painting that is the source of the images used for War Cut. There is no necessary relationship, thematic or otherwise, between $648-2$ and its re-use in the newer work. Further, only after he had already gathered these images for publication in a book, and months after the war's beginning, did Richter decide that the theme of the Iraq war would be the book's organizing principle (Richter in Thorn-Prikker 2004: n.p.). Even in Richter's mind, the close-up images initially had no conceptual or natural correspondence to the theme of war.

Further, there are a number of confused statements about the material nature of War Cut. Thorn-Prikker himself provides conflicting information about War Cut's key facts. ${ }^{11}$ His 2004 interview with Richter is titled "One Picture is Worth 216 Newspaper Articles" despite the fact that in the book there are 216 images, not one (presumably, Thorn-Prikker is referring to the singular source painting, which, as demonstrated, plays a minor role in the perception of the book). ${ }^{12}$ Thorn-Prikker also proposes conflicting publication dates for the original newspaper articles in different essays, one article suggesting that the dates are March 20 and 21, 2003 (clearly the correct dates) while another states that they are from March 22 and 23. As for the text fragments, Thorn-Prikker's essays again conflict, variously suggesting that War Cut contains either 165 or 216 newspaper articles. There are, in fact, 155 distinct articles, spread out over 185 pages, divided into the 216 visual blocks, corresponding

\footnotetext{
${ }^{11}$ The two sources are by Thorn-Prikker. One is "War-Cut: A Dark Mirror," in the 2004 issue of Kulturjournal from the Goethe Institute, the other is the above New York Times interview with Richter.

12 Thorn-Prikker, 2004a, n.p. Granted, there is a singular source for the multiple images; but this fact seems utterly beside the point as Richter transforms these 216 details so radically that they become distinct images.
} 
in position and size to the images. As if confusion about the details of War Cut's clippings were not enough, the New York Times had a problem reproducing No. 648-2 when it was published alongside Thorn-Prikker's interview. On 18 July 2004, a full two weeks after its initial publication, the Times printed the following correction: "A picture on July 4 with an article about Gerhard Richter's book War Cut, depicting his abstract painting No. 648-2, was reproduced upside down and in reverse. The corner with the concentration of orange paint should have been at the upper right, not the lower right" (The New York Times, 18 July 2004).

My account of the seemingly arbitrary nature of Richter's War Cut and its resulting confused representation is not meant to once again rehearse the argument that abstraction is an arbitrary form of expression; nor is it to disparage Thorn-Prikker, whose work I find quite interesting; nor is it to point to the slipping editorial oversight in the New York Times. These errors of fact and understanding, however, raise profound questions about the contemporary artist's ability to represent history: Do the details, of time, place, and orientation matter? When Richter celebrates the "uncommunicative" aspect of his work, how is the viewer, who is searching for the communicative value in contemporary events, supposed to respond $?^{13}$ What does his thwarting of the viewer's desire for opinion, statement, message or proposition mean? If Richter has resuscitated history painting for the contemporary age, as some suggest, what kind of memory of the past does it prompt? Is it correct to find War Cut or any of Richter's other historical representational paintings, as Thorn-Prikker suggests, "an attack on forgetting" (Thorn-Prikker, 2004a: n.p.)? Or is War Cut's indirect relation to reality rather an attack on remembering? Richter himself makes the connection between War Cut and 18. October 1977 in this regard:

War Cut only very indirectly involves reality...I like to think that maybe by removing the headlines I contributed toward having these texts read as literature. It would be like taking a newspaper photo and putting it in a museum as an oil painting, which is I suppose what I did with Baader-Meinhof (Richter in Thorn-Prikker, 2004).

War $\mathrm{Cut}$ and the Baader-Meinhof works also share a delayed response to the events that motivate their forms. In the case of War Cut the delay was from Richter's completion of the painting 648-2 in 1987 to his taking photographs of it in 2002, to the use of these photo-details in the book published in 2004. The delay between the Baader-Meinhof events of 1977 and Richter's painting of them in 1988 was also more than a decade. One might compare Richter's delay in both cases to Max Horkheimer's suggestion that one should read the daily newspaper at a two-week delay. At this temporal distance, the news cycle's sensationalism, designed to keep us frenzied and distracted (a situation that has only become more pronounced), is tempered by our inability to react instantaneously. At this two-week delay, one is forced to weigh the significance of information on a larger scale and to respond with critical distance. Likewise, Richter's temporal shift sets aside the viewer's desire to act on behalf of the subject and to instead reflect on one's immediate experience. War Cut, which almost exactly follows the length of Horkheimer's temporal delay from precipitating event to creation, nevertheless does so with a greater emotional remove than 18. Oktober 1977 by using arbitrary compositional arrangements and abstract imagery; whereas the Baader-Meinhof series' greater temporal remove is mitigated by the greater accessibility of its representational form. The desire to take sides, formulate a position, gauge a response, intervene in history cannot be fulfilled in the delayed case of the more final/fatal RAF images.

\footnotetext{
13 Thorn-Prikker, 2004. The more complete quote is: I read most of the texts [in War Cut] only after I placed them with the pictures. I read them as literature, which was very pleasing. I was not looking for straightforward narrative, which is maybe also why I chose that particular abstract painting. Some of my other abstract pictures are less ambiguous. Their atmosphere is either very agitated or tranquil or almost storylike in their narrative flow, so that they seem nearly representational or surreal. This picture had none of that. It was close to being uncommunicative, which I don't mean negatively.
} 


\section{Conclusion: Two Strategies Compared}

If War Cut and 18. Oktober 1977 both elevate the arbitrary, banal facts and images of contemporary history to aesthetic meditations on image, memory and text, the Baader-Meinhof series does so more successfully because its greater iconicity mitigates arbitrariness with identification. In it, Richter most effectively fuses historical tragedy, photographic veracity, and painterly effect into a fugue of funerary solemnity. Our present dealings with war and terrorism are both more immediate and less personal and the magnitude of tragic circumstances prevents easy assimilation. Despite the five-year time lapse before the release of cinematic meditations on 9/11, apparently this had not yet been enough time for film directors to develop a more epic treatment of the subject.

In his review of two 9/11 films, Daniel Mendelsohn notes how the ancient Greeks addressed their eight-year-old violent victory over Persia in the form of Aeschylus' play The Persians (Aeschylus 472 B. C. E.). Mendelsohn suggests that the successful reception of the play by the Athenians can be accounted for not merely by the delay of the production by the eight years that had passed since the war. Rather, the more potent reason for its greatness and significance came from the way in which Aeschylus made the enemy (the Persians) not the Greeks, the main characters of the play. By foregrounding Persian characters, Aeschylus forced the Athenians to empathize with their enemies, with their defeat rather than permitting them to revel in self-congratulatory rhetoric about Greek victory:

Which is to say that in the very moment of their greatest victory, he asked his fellow Athenians to think radically, to imagine something outside of their own experience, to situate the feelings they were having just then - about themselves, about those others - in a vaster frame: one in which they might see that present triumph could induce a complacency that just might bring about future disaster (Mendelsohn 2006, n.p.)

Richter's 18. Oktober 1977 similarly engages with the weighty matter of contemporary history by "resituating" feelings that elicit empathy rather than reaffirm ideological correctness. War Cut, in its abstraction and conceptual gamesmanship, sets itself the task of methodically refusing identification and empathy. In Oliver Stone's problematically conceived World Trade Center (2006), Dave Karnes, one of the heroic characters, opines at the still smoldering Twin Towers site: "It's like God made a curtain with the smoke, shielding us from what we're not yet ready to see" (Stone, 2006). The veiled imagery in Richter's photopaintings similarly seems like the smoke of the piled-up disasters of modern history, hanging in the air between our present and this inaccessible and irretrievable past.

Richter's "fog," however, is strategic rather than protective. It creates the very distance that aesthetic appreciation requires. Alternately concealing and revealing the dreams and nightmares of modernity, Richter dramatizes the moment of the reappearance of our memories. His visual occlusion rescues representation from the grip of fevered ideological reaction, causing a hesitancy and delay that enlivens our response by making our perception itself an object of reflection. War Cut's abstract, arbitrary and conceptual mode of expression is an accurate reflection of the type of rhetoric and warfare employed in the Iraq War. But the cost of his conceptual gamesmanship is a walling-off of empathic identification, whether with its perpetrators or victims. Richter's 18. Oktober 1977, on the other hand, aesthetically achieves empathic identification without compromising the complicated historical facts of its subject. The work is a remarkable achievement in grappling with terrorism, politics and human cost.

\section{Works Cited}

Adorno, T. 2001. "The Culture Industry Reconsidered" (1963), in J. M. Bernstein (ed.): The Culture Industry: Selected Essays on Mass Culture, London: Routledge.

Aeschylus 472 B.C.E. The Persians. Translated by Robert Potter, http://classics.mit.edu/Aeschylus/persians.html, retrieved on 10 July 2017.

Barthes, R. 1981. Camera Lucida, New York: Hill and Wang.

Benjamin, W. 1931/1972. "A Short History of Photography," republished in Screen 1972 (trans. Stanley Mitchell), vol. 13, no. 3, 5-26. 
Buchloh, B. 1998. "Warburg's Paragon?: The End of Collage and Photomontage in Postwar Europe," in Ingrid Schaffner, Nikolaus G. Schneider, Claudia Seelmann, Matthias Winzen, Christopher Wynne, (eds.), Deep Storage: Collecting, Storing, and Archiving in Art (trans. Pauline Cumbers, New York: Prestel-Verlag.

Germer, S. 1992. "Retrospective Ahead" in Seam Rainbird and Judith Severne (eds.): Gerhard Richter, London, The Tate Gallery.

Gibbons, J. 2007. Contemporary Art and Memory, London: I.B. Tauris \& Co. Ltd.

Heyme, H. "Trauerarbeit der - Kunst muss sich klarer geben," Art: Das Kunstmagazin April 1989, vol. 4: 15.

Hirsch, M. 2008. "The Generation of Postmemory," Poetics Today, vol. 29 no.1, 103-128.

1977. Family Frames: Photography, Narrative and Postmemory, Cambridge MA and London: Harvard University Press.

Hustvedt, S. 2002. "Double Exposure," Modern Painters, Summer 2002, vol. 15, no. 2: 48-57.

Mendelsohn, D. 2006. "September 11 at the Movies," The New York Review of Books, vol. LIII, no. 14, 21 September 2006, http://www.nybooks.com/articles/2006/09/21/september-11-at-themovies/, retrieved on 21 September 2015.

New York Times, 2004. “Corrections," Books Section, http://www.nytimes.com/2004/07/18/books/ccorrections-294195.html?_r=0, retrieved 10 July 2017.

Perniola, M. 1995. Enigmas: the Egyptian Moment in Society and Art, trans. by Christopher Woodall, New York: Verso.

Richter, G. 1995. Gerhard Richter: The Daily Practice of Painting, London: Thames \& Hudson.

Richter, G. 2004. War Cut, published by Hans-Ulrich Obrist and Suzanne Page, Cologne: Walther König Publishers.

Storr, R. 2002. "Gerhard Richter: The Day is Long," Art in America, 1 January 2002, vol. 90, no. 1: 66-75, http://www.artinamericamagazine.com/news-features/magazine/gerhard-richter-robertstorr/, retrieved on 10 July 2017.

Storr, R. 2003. Gerhard Richter, Doubt and Belief in Painting, New York: Museum of Modern Art.

Thorn-Prikker, J. 2004. "A Picture is Worth 216 Newspaper Articles," New York Times, Art and Leisure section, July 4, 2004; accessed via NYT online database.

Thorn-Prikker, J. 2004(a). "War Cut - A dark mirror: An artist's book by Gerhard Richter", Kulturjournal, retrieved in July 2007: http://www.goethe.de/wis/ bib/prj/kjl/aus/en215220.htm

World Trade Center. Dir. Oliver Stone. Perfs. Nicholas Cage, Maria Bello, Michael Peña, Maggie Gyllenhaal, Stephen Dorff and Michael Shannon. 2006. Paramount Pictures, 2006.

All images (C) Gerhard Richter 2017 (14072017) 